DOI: $10.35757 /$ CIV.2007.10.13

\title{
Kim są Amerykanie?
}

Samuel P. Huntington: Kim jesteśmy? Wyzwania dla amerykańskiej tożsamości narodowej, przekład Bartłomiej Pietrzyk, Wydawnictwo Znak, Kraków 2007.

Samuel P. Huntington, znany $z$ wieszczenia zderzenia cywilizacji, co miało się jawnie potwierdzić w ataku terrorystycznym 11 września 2001 roku, tym razem zajął się kwestia tożsamości amerykańskiej. Zagadnienie to przewijało się w jego pracach już od dawna, niemniej dopiero teraz przedstawił prawie 400stronicowe opracowanie poświęcone meandrom tożsamości amerykańskiej. Już wcześniej Huntington alarmował w artykule Latynoskie wyzwanie, iż powiększająca się wciąż latynoska emigracja, nie chcąc się asymilować, stanowi duże zagrożenie dla kultury amerykańskiej ${ }^{1}$. W Kim jesteśmy rozwija swe tezy.

Książka, wydana w Stanach Zjednoczonych w 2004 roku, zdążyła już wzbudzić tam ogromne kontrowersje - Huntingtonowi zarzucano amerykanocentryzm, rasizm, skrajny konserwatyzm. Zdarzały się też zarzuty cięższe, m.in. takie, że dotąd nie napisał książki tak źle i słabo uargumentowanej, odwołującej się na dodatek do tanich chwytów.

Jak sam autor mówi na wstępie, chciałby nie tylko zgłębić istotę amerykańskiej tożsamości narodowej, ale także prześledzić jej przemiany. I choć ksiązka pozostaje w kręgu kultury amerykańskiej, możemy znaleźć w niej również odzwierciedlenie problemów dotyczacych Europy, w tym także Polski. Większość bowiem krajów europejskich boryka się $z$ trudnym problemem imigrantów, $z$ kwestiami asymilacji

1 S.P. Huntington: The Hispanic Challenge, „Foreign Policy”, marzec-kwiecieñ 2004, s. 30-45. Por. też Special Case of Mexican Immigration: Why Mexico Is a Problem, „The American Enterprise" 2000, nr 11 (8) Dec., s. 20-22. 
ich odmiennych kultur. Towarzyszy temu nie tylko lęk przed obcym, ale także obawa przed utratą części własnej tożsamości.

Huntington już w Zderzeniu cywilizacji wieścił zagrożenie ze strony innych cywilizacji (głównie dla cywilizacji amerykańskiej). Tak do końca nie wiadomo jednak, kto konkretnie miałby stanowić największe zagrożenie dla cywilizacji amerykańskiej. $Z$ jednej bowiem strony niepokojąca wydaje się dla interesów narodowych Ameryki cywilizacja islamu, $z$ drugiej zaś - wydawałoby się, nie tak odległa kulturowo - ludność latynoamerykańska.

Mimo to do 11 września wydawało się, że Ameryka nie ma jasno określonych wrogów. W związku $z$ tym miała kłopoty ze swoja tożsamością. Od czasów zakończenia zimnej wojny nie wiadomo było bowiem, wobec kogo się określać.

„Najgłębsze pytanie o rolę Ameryki w świecie po zimnej wojnie zadał niespodziewanie Rabbit Angstrom, udręczony bohater powieści Johna Updike'a: „Jaki sens być Amerykaninem, skoro nie ma już zimnej wojny?”. Rzeczywiście, „jeśli bycie Amerykaninem oznacza oddanie sprawie wolności, demokracji, indywidualizmu i prywatnej własności, a wrogie tym ideałom imperium zła zniknęło - to co właściwie znaczy być Amerykaninem i co jest amerykańskim interesem narodowym?" - pisał w 1998 roku Huntington ${ }^{2}$.

Co ciekawe, nie upatrywał wówczas w islamie możliwości uznania go za wroga powodującego odrodzenie tożsamości narodowej. Bardziej kładł nacisk na zagrożenie ze strony imigrantów, głównie latynoamerykańskich, niechętnych asymilacji pod sztandarem amerykańskich wartości, a także wszelkie związane $z$ tym ideologie sławiące różnorodność i wielokulturowość. Już jednak w Kim jesteśmy, książce wydanej po 11 września, zauważa i docenia ogromny wybuch patriotyzmu wśród Amerykanów, a także związane $z$ tym wzmocnienie tożsamości amerykańskiej. Wielu ludzi, którzy dotąd, mówiąc o sobie, „bycie Amerykaninem stawiali daleko za innymi samookreśleniami, przetasowało swoje hierarchie wartości. Po

2 S. Huntington: Stany Zjednoczone, tożsamość narodowa, „Gazeta Wyborcza”, 9 maja 1998. 
11 września Ameryka, która na moment zapomniała o swej tożsamości, znów przeżyła renesans narodowego patriotyzmu. Objawiło się to $\mathrm{w}$ iście amerykański sposób - Amerykanie, którzy i tak nad wyraz wielbia swoja flagę, po 11 września zaczęli ją umieszczać dosłownie wszędzie - na domach prywatnych, w witrynach sklepów, na koszulkach, czapeczkach itd. Przemiany patriotyczne, jakie przytacza Huntington w Kim jesteśmy, stanowia niekiedy swoisty szczyt grafomaństwa politycznego i przybieraja rozmiary histerii ogólnonarodowej (por. np. s. 17-18).

Huntington wyraźnie dzieli więc Amerykę na tę przed i po 11 września. Jako przyczyny chwilowej utraty tożsamości przywołuje - jak zwykle - największe zmory współczesnego, w dużej mierze liberalnego świata: globalizację, wielokulturowość, kosmopolityzm, imigrację, subnacjonalizm, antynacjonalizm.

Gdzie autor upatruje ratunku? Bo, rzecz jasna, impuls po chwilowym zagrożeniu terroryzmem to jedynie przebudzenie i powrót do tego, co wedle Huntingtona najbardziej wartościowe - czyli kultury anglo-protestanckiej. Kulturę tę czasem określa się jako kulture White Anglo-Saxon Protestants (WASP). Ona nie tylko stworzyła Amerykę, lecz także pozwoliła jej przetrwać oraz zadecydowała o jej charakterze jako supermocarstwa. To również kultura, jak powiada Huntington, która pozwoliła stworzyć wielorasowe i wieloetniczne społeczeństwo. „To właśnie Ameryka która znam i kocham. To również - jak udowadniam w tej książce - Ameryka, która kocha i której pragnie większość Amerykanów" (s. 13) pisze Huntington, a co zapowiada, że najnowsze dzieło amerykańskiego politologa będzie wielka apologia jego ojczyzny.

Główne tezy swej książki Huntigton przywołuje już na początku. Po pierwsze, znaczenie tożsamości narodowej dla Amerykanów zmienia się w czasie. Kilka istotnych dat to: koniec XVIII wieku, początek XIX wieku (kiedy to miało miejsce jej kształtowanie się), lata sześćdziesiąte XX wieku oraz najważniejsza cezura czasowa 11 września 2001 roku. Po drugie, inne kategorie przynależności, takie jak rasowe czy etniczne, właściwie zupełnie zniknęły bądź 
też straciły na znaczeniu. Pozostaja tylko kategorie ideologiczne i kulturowe. Wyznacznikami amerykańskiego credo ${ }^{3}-\mathrm{w}$ którego istnienie tak mocno wierzy Huntington, i na które kładzie nacisk - sa język, religia, zaangażowanie, anglosaska koncepcji rządów prawa, wartości protestanckie, etyka pracy, indywidualizm i prawa jednostki. Po trzecie, napływ emigrantów z Ameryki Łacińskiej i Azji stawia tę tożsamość pod znakiem zapytania.

Zanim jednak Huntigton zajmie się problemami współczesnej Ameryki, poświęca dużą część książki na rozważania teoretyczne na temat pojęć kultury oraz tożsamości i jej źródeł. Ta część nie obfituje w szczególnie ciekawe spostrzeżenia, zawiera jedynie podsumowanie kwestii, o których można przeczytać w większości publikacji. Interesujace sa natomiast te fragmenty, w których autor odwołuje się do realiów amerykańskich.

Według Huntingtona amerykańskie credo, będace wyznacznikiem tożsamości, zaczęło się ujawniać dopiero pod koniec XVIII wieku. Do tego czasu Amerykanie określali się w kategoriach rasy, przynależności etnicznej, kultury, a przede wszystkim religii. Dopiero $\mathrm{w}$ momencie pogorszenia się stosunków z Wielką Brytanią, wraz z rodzaca się potrzeba uniezależnienia, zaczęto szukać innego uzasadnienia własnej tożsamości niż to, które dotąd było wspólne z Brytyjczykami. I choć oczywiście główne składniki owego credo maja korzenie anglosaskie, to jednak, zdaniem Huntingtona, kultura amerykańska w ostateczności ukształtowała się odmiennie. Co ważne w tym rozróżnieniu, amerykańska tożsamość - jako będąca niejako „obywatelską", czyli określona przez zestaw zasad - zyskuje przewage nad tożsamościa czysto etniczną czy też etniczno-kulturowa innych społeczeństw. Pozwala to twierdzić Amerykanom, że ich kraj jest zarazem wyjątkowy i uniwersalny - jego zasady daja się zastosować do każdego narodu na świecie.

Huntington przyznaje, że swoista mieszanka kultury anglo-protestanckiej była, jest i powinna zostać dominująca, jeśli nie jedyna 
możliwością w Ameryce, jeśli Ameryka ma zamiar pozostać tym, czym była dotą, i za co, jak na początku sam zadeklarował, ją kocha, a także, w jego mniemaniu, kocha ja większość Amerykanów. Swoją droga, chyba w takim stwierdzeniu nie ma na myśli rosnacej rzeszy imigrantów zza południowej granicy, a także $z$ odległej Azji. W Huntingtonowskim rozumowaniu Amerykanin to człowiek, który przyswoił owa kulturę amerykańska, innej możliwości być nie może. Tak się działo na przestrzeni dziejów, to przynosiło krajowi same korzyści i pozwalało budować jego potęgę. Dziś nie można pozwolić na zaprzepaszczenie dokonań przodków.

Autor mówi o kulturze anglo-protestanckiej, choć właściwie sam przyznaje, że protestantyzm jako religia już dawno przestał być dominujacy wśród napływającej ludności. Przekonuje jednak, że wartości protestanckie przetrwały w kulturze i jako takie moga funkcjonować w oderwaniu od religii.

Kolejnym ważnym momentem dziejowym dla kształtowania się amerykańskiej tożsamości była druga wojna światowa. Wraz $z$ jej zakończeniem Ameryka przestała się postrzegać w roli przeciwnika Europy. Przyjęła rolę przywódcy całego świata zachodniego, w walce $z$ czerwona Rosja i Chinami. A potem nastapił kres zimnej wojny i naturalny brak cementowania amerykańskiego poczucia jedności. Wzrost poczucia tożsamości narodowej nastapił na chwilę (Huntington mówi o dwóch latach) po 11 września.

Jednak już wcześniej, w latach sześćdziesiątych XX wieku, w wyniku ruchów społecznych, co niewatpliwie powiąane było również $z$ narastającymi falami imigrantów, koncepcja Ameryki jako jednolitego organizmu zjednoczonego wokół takich samych (anglo-protestanckich) wartości była coraz mocniej nadszarpywana. Dekonstrukcjoniści owej jedności opowiadali się za wzrostem znaczenia subnarodowych grup rasowych, etnicznych i kulturowych. Potępiali przymusową asymiliację, a nawet namawiali do zachowywania kultury swojego kraju. Ruch ten doprowadził do szerokiej debaty publicznej nad pojęciem narodu, problematyka imigracji i asymilacji. $Z$ początkiem lat dziewięćdziesiątych ruch ten uległ znacznemu osłabieniu. 
Wszelkie takie próby Huntington uznaje za wyzwanie rzucane amerykańskiemu credo. Każdy, kto nie chce pełnej asymiliacji pod sztandarem uniwersalnych wartości amerykańskich uznawany jest przez niego za przeciwnika tych wartości. A przecież sa to wartości uniwersalne - godność równość, wolność, sprawiedliwość, uczciwe szanse - choć oczywiście sa to tylko idee i w zasadzie nigdy, w całej historii Ameryki, nie zostały w pełni wcielone w życie. Dlatego też niektórzy skłaniali się ku przykrojeniu owych ideałów do rzeczywistych wartości praktykowanych przez obywateli. Huntington wierzy, że to właśnie jednak amerykańskie credo pozwoliło stworzyć wielokulturowe, wieloetniczne społeczeństwo, doprowadzajac do zakończenia segregacji i dyskryminacji rasowej. Dlatego też $\mathrm{w}$ żadnym razie nie należy $\mathrm{z}$ niego rezygnować, choćby jako $z$ nieosiagalnego ideału. Nasuwa się jednak pytanie, czy w takim razie społeczeństwo amerykańskie ze swoimi szczytnymi ideałami samo na siebie ukręciło bicz? Czy też jednak przekonanie Huntingtona o tolerancyjności narodu amerykańskiego jest nieco nazbyt optymistyczne?

Mimo więc, że Ameryka obecnie nie ma żadnego „naturalnego" wroga w postaci supermocartswa, istnieja inne zagrożenia „rozsadzenia" jej niejako od środka - zagrożenia te stanowia rosnące rzesze imigrantów, głównie latynoamerykańskich. Huntington wyraża obawę nie tylko o powstająca $\mathrm{w}$ związku $\mathrm{z}$ tym erozję obywatelstwa, zanik tradycyjnej, hołubionej przez niego tożsamości amerykańskiej, ale wręcz wieszczy (a biorac pod uwagę siłę jego wizji, być może należy je traktować całkiem realnie) podział kraju na dwie części - anglojęzyczną i hiszpańskojęzyczną.

Pozostaje zadać pytanie, dlaczego dopiero teraz imigranci maja być przyczyna upadku potęgi Ameryki, skoro dotychczas przyczyniali się do jej wzrostu? Wszak Ameryka to kraj imigrantów, ludność rdzenna już dawno została zagoniona do rezerwatów. Do tej pory - odpowiada Huntington - imigracja wiązała się $z$ pełna asymilacja społeczno-kulturowa, zazwyczaj już drugie pokolenie było w pełni zasymilowane, czyli w rozumieniu autora stawało się 
prawdziwymi Amerykanami, wyrzekając się tym samym własnych tożsamości narodowych. Jak pisze: „Podstawowym problemem Ameryki nie jest imigracja, lecz to, czy towarzyszy jej asymiliacja. W jakim stopniu ci imigranci, ich następcy oraz potomkowie podą̇a ścieżka wcześniejszych imigrantów zostana zasymilowani społecznie i kulturowo przez Amerykę, stana się zdeklarowanymi Amerykanami, odrzucającymi inne tożsamości narodowe, a ich przekonania i czyny będa wyrazem wiary w zasady amerykańskiego credo?” (s. 166).

Tymczasem imigranci $z$ Południa, zwłaszcza zaś Meksyku, uparcie nie chca się asymilować. Takie zjawisko nie ma, zdaniem Huntingtona, precedensu $\mathrm{w}$ historii Ameryki. Ludność hiszpańskojęzyczna nawet $\mathrm{w}$ czwartym pokoleniu nadal odstaje od standardów amerykańskich pod względem poziomu wykształcenia oraz statusu społecznego i ekonomicznego. Sprzyja $z$ pewnościa temu łatwość przekraczania granic - dawniej wyemigrowanie do Ameryki wiązało się $z$ wieloma przeszkodami, co automatycznie pozwalało przedostać się tam jednostkom najbardziej operatywnym i silnym. Te cechy zaś sprzyjały osiagnięciu sukcesu na miejscu.

Koncentracja ludności imigracyjnej ułatwia utrwalanie się używania języka hiszpańskiego w następnych pokoleniach. Na dodatek wywiera $\mathrm{w}$ ten sposób presję na pozostałych Amerykanach, aby respektować ich odmienność w tej materii. Jako dowód na to przytaczana jest wypowiedź prezydenta Clintona, iż ma nadzieję być ostatnim prezydentem nie znającym języka hiszpańskiego.

W ostatecznym rozrachunku doprowadzi to do dyskryminacji, tym razem Amerykanów anglo-protestanckich. Zostaną on zmuszeni do dostosowania się lub opuszczenia terenów zajętych przez ludność latynoską. Poza tym imigranci jako silna grupa zaczna wywierać coraz większy wpływ na rządzenie krajem, na gospodarkę, a także na kulturę i wartości. Wedle Huntingtona będzie to prosta droga do upadku Ameryki. Będzie to koniec Ameryki, jaka znamy od wieków - nieco histerycznie woła Huntington - a nowo powstały twór może być w jego ocenie zapewne tylko gorszy. 
W rozdziale podsumowującym Huntington przedstawia trzy możliwości dalszego rozwoju Ameryki. Pierwsza $z$ nich to kosmopolityczne otwarcie się na świat, $z$ jego wieloetnicznościa, wielorasowością, wielokulturowością. Różnorodność będzie hasłem nadrzzędnym, a przeciętny Amerykanin będzie się stosował nie do zasad wyznaczonych przez rząd federalny czy rządy stanowe, lecz przez różne organy międzynarodowe takie jak ONZ, Światowa Organizacja Handlu, Sąd Światowy, międzynarodowe prawo zwyczajowe. Tożsamość narodowa straci na znaczeniu. Czyli, jak mówi Huntington: „W alternatywie kosmopolitycznej świat przekształci Amerykę" (s. 323). W drugiej wizji, czyli imperialnej, to Ameryka przekształci świat. Ameryka już znajdowała się w roli imperialisty, i duża część Amerykanów zapewne chętnie nadal by ją w ten sposób postrzegała. Zdaniem Huntingtona jednak najlepszym wyjściem i pożądanym przez przeważającą większość społeczeństwa amerykańskiego jest model państwa narodowego. $Z$ umocniona tożsamościa, $z$ amerykańskim credo jako jedynym modelem bycia Amerykaninem. Że zaś wybór drogi obranej przez jego ojczyznę wpłynie na losy całego świata, co do tego Huntington nie ma watpliwości.

Lektura Kim jesteśmy pozostawia czytelnika $z$ nieco mieszanymi uczuciami. $Z$ jednej strony autor aspiruje bowiem do wyczerpującego opracowania kwestii tożsamości, uwzględniając spojrzenie historyczne, $z$ drugiej zaś książka czasem sprawia wrażenie chaotycznego przedstawiania faktów, podporzadkowanych $z$ góry postawionej tezie. Ponadto kręcenie się wokół pojęcia credo, w sposób niewiele wnoszący, bez nowych spostrzeżeń, po jakimś czasie nuży i osłabia siłę przekonywania. $Z$ argumentacja swojego stanowiska Huntington często miewa problemy. Zapewne w swym mniemaniu wypowiada oczywistości i stwierdzenia nie potrzebujące uzasadniania naukowego, co sprawia, że niejednokrotnie odchodzi w kierunku publicystyki.

Jeśli zaś chodzi o kwestie merytoryczne, Huntington niejednokrotnie poddaje się latwym, acz chwytliwym uproszczeniom, na przykład wyrażając tak silna wiarę $\mathrm{w}$ istnienie jednolitych warto- 
ści wyznawanych w Ameryce. Alan Wolfe, amerykański publicysta w „Foreign Affairs” wyraził przekonanie, że wręcz trudno mówić o jednolitej kulturze protestanckiej w obliczu tylu istniejących niezgodności wśród Kościołów protestanckich w Ameryce. Inni krytycy wytykaja mu błędy dotyczące faktów. Między innymi przywołując ogromna liczbę osób pochodzenia latynoamerykańskiego, które to przyjęły religie protestancką. Ma to się przeciwstawiać tezie Huntingtona o braku asymilacji wśród tej grupy. Oczywiście, łatwo można manipulować danymi w celu dowiedzenia uprzednio postawionej tezy. Można bowiem na przykład stwierdzić, iż jest to asymilacja $\mathrm{w}$ gruncie rzeczy pozorna.

Inny zarzut dotyczy braku logiki w argumentacji Huntingtona. Zastanawia na przykład, w jaki sposób Huntington godzi tę propagowana tolerancję, równość $\mathrm{i}$ indywidualizm $\mathrm{z}$ amerykańskiego credo $z$ koniecznością dostosowania się ludzi do jednego wzorca. Jeśli miałby to być wzorzec tak pojemny, jak wynikałoby $z$ deklaracji ideologicznej, byłoby tam miejsce dla wszystkich Ameryk. Huntigton jednak widzi to inaczej, co nie przekreśla faktycznego problemu imigrantów. Powstaje tylko pytanie, czy proponowane przez niego rozwiąania sa tymi najwłaściwszymi. Być może ta książka ma prawo oburzać (faktycznie, niektóre stwierdzenia ocierają się o rasizm) być może autor nagina pewne fakty, ale niewatpliwie wyraża sposób myślenia pewnie nie całej, ale sporej części Ameryki, Ameryki nie liberalnych intelektualistów, ale przeciętnych mieszkańców. Być może dzięki takiemu świętemu oburzeniu, w dużej mierze uzasadnionemu, Huntington zwrócił uwage na faktycznie istniejące problemy - choć nie w taki sposób, jak by zapewne tego oczekiwał.

Żaneta Oczkowska

Żaneta Oczkowska-zob. s. 171. 